\title{
Examining The Day Of The Week Effect In Istanbul Stock Exchange (ISE)
}

Murat Cinko, Marmara University, Rep. of Turkey

Emin Avci, Marmara University, Rep. of Turkey

\begin{abstract}
The existence of day of the week effect for Istanbul Stock Exchange (ISE) was analyzed on the basis of ISE-100 index returns, the returns of all stocks traded in ISE and market capitalization based portfolio returns during 1995-2008. In line with the previous findings, the results of the study presented that the ISE-100 index, ISE traded stocks and market capitalization based portfolios had significant negative Monday and significant positive Thursday and Friday returns.
\end{abstract}

Keywords: Day of the week effect; market efficiency

\section{INTRODUCTION}

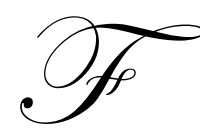

or over a century, investors and academicians around the world have been studying to figure out the way the security prices fluctuate. Although several academicians suggested various theories to explain the securities price movements in the financial markets, there is no consensus on the validity of those theories and a few could survive to the current decade. One of these theories is the Efficient Market Hypothesis (EMH).

Since its introduction by Eugene Fama (1965), the validity EMH has been questioned on several aspects. One of the critics directed to EMH is the existence of price anomalies, like reoccurrence of similar price patterns in the stock market during a trading day; week or year or period. These anomalies are generally called as the day of the week effect, January effect, and turn of the month effect.

This study will investigate the existence of day of the week effect in Istanbul Stock Exchange (ISE). Although, the evidences about the day of the week effect anomaly in ISE had been documented by several studies; the findings of those studies were based on market indexes, like ISE-100 index. However, this study investigated the existence of the day of the week effect on stock basis by examining the returns of each stock traded on ISE and market capitalization based portfolio returns.

The study is organized as follows. Section two summarizes the literature on the day of the week effect anomaly; section three provides the research design of the study; section four presents the empirical findings and the last section concludes.

\section{LITERATURE REVIEW}

Several studies were devoted to investigate the existence of day of the week effect anomaly in developed stock markets. Among the studies that examined the US stock markets documented that daily stock returns tend to be negative on Mondays, and tend positive on Fridays (Cross, 1973; French, 1980; Gibbons and Hess, 1981; Keim and Stambaugh, 1984; Rogalski, 1984). On the other hand, several other evidences for the existence of day of the week effect were also reported for developed stock markets (Kiymaz and Berument, 2003; Gregoriou et.al., 2004).

Furthermore, in several studies, the evidences for the day of the week effect was also documented for the developing stock markets (Brooks and Persand, 2001; Chusanachoti and Kamath, 2002, Demirer and Karan, 2002; Ajayi, et.al., 2004; Tonchev and Kim, 2004; Hui,2005; Cinko, 2008). 


\section{RESEARCH DESIGN}

Istanbul Stock Exchange (ISE), as the only stock market in Turkey, was inaugurated in late 1985 and began operation in 1986. The Istanbul Stock Exchange characterized with high volatility in the market returns since its establishment. Such volatility attracts many local and foreign investors as it provides high return possibility. Besides the financial crises realized since the establishment of the market, ISE presented an outstanding growth as an emerging market. The number of companies listed in the ISE increased to 284 in 2008 while it was 80 in 1986. Total trading volume and the total market capitalization were $\$ 261.274$ billion and $\$ 119.698$ billion in 2008, respectively. Table 1 reports key market indicators for the years between 1986 and 2008.

Table 1 ISE Key Indicators

\begin{tabular}{|c|c|c|c|c|c|}
\hline Year & $\begin{array}{l}\text { Number of } \\
\text { Companies } \\
\text { (Yearend) }\end{array}$ & $\begin{array}{l}\text { Traded Value } \\
\text { (US\$ Million) }\end{array}$ & $\begin{array}{c}\text { Traded Number of } \\
\text { Stocks }\end{array}$ & $\begin{array}{c}\text { Total Market } \\
\text { Values of the } \\
\text { Companies } \\
\text { (US\$ Million) } \\
\end{array}$ & $\begin{array}{c}\text { ISE-100 Closing } \\
\text { Values } \\
\text { (US\$) }\end{array}$ \\
\hline 1986 & 80 & 13 & 3 & 938 & 131,53 \\
\hline 1987 & 82 & 118 & 15 & 3.125 & 384,57 \\
\hline 1988 & 79 & 115 & 32 & 1.128 & 119,82 \\
\hline 1989 & 76 & 773 & 238 & 6.756 & 560,57 \\
\hline 1990 & 110 & 5.854 & 1.537 & 18.737 & 642,63 \\
\hline 1991 & 134 & 8.502 & 4.531 & 15.564 & 501,50 \\
\hline 1992 & 145 & 8.567 & 10.285 & 9.922 & 272,61 \\
\hline 1993 & 160 & 21.770 & 35.249 & 37.824 & 833,28 \\
\hline 1994 & 176 & 23.203 & 100.062 & 21.785 & 413,27 \\
\hline 1995 & 193 & 52.357 & 306.254 & 20.782 & 382,62 \\
\hline 1996 & 213 & 37.737 & 390.924 & 30.797 & 534,01 \\
\hline 1997 & 244 & 58.104 & 919.784 & 61.879 & 981,99 \\
\hline 1998 & 262 & 70.396 & 2.242 .531 & 33.975 & 484,01 \\
\hline 1999 & 256 & 84.034 & 5.823 .858 & 114.271 & $1.654,17$ \\
\hline 2000 & 287 & 181.934 & 11.075 .685 & 69.507 & 817,49 \\
\hline 2001 & 279 & 80.400 & 23.938 .149 & 47.689 & 557,52 \\
\hline 2002 & 262 & 70.756 & 33.933 .251 & 34.402 & 368,26 \\
\hline 2003 & 264 & 100.165 & 59.099 .780 & 69.003 & 778,43 \\
\hline 2004 & 274 & 147.755 & 69.614 .651 & 98.073 & $1.075,12$ \\
\hline 2005 & 282 & 201.763 & 81.099 .503 & 162.814 & $1.726,23$ \\
\hline 2006 & 290 & 229.642 & 91.634 .552 & 163.775 & $1.620,59$ \\
\hline 2007 & 292 & 300.842 & 116.824 .185 & 289.986 & $2.789,66$ \\
\hline 2008 & 284 & 261.274 & 114.793 .157 & 119.698 & $1.027,98$ \\
\hline
\end{tabular}

Source: ISE Annual Fact Book 2008.

This study examined the existence of day of the week effect for ISE-100 index and 324 stocks traded in ISE throughout 1995 - 2008. The data set was composed of daily returns for 324 stocks and the total number of returns 819,726 . Among these stocks, minimum number of observation for a stock in the data set was 248 and the maximum number of observation for a stock was 3406 .

The returns for stocks and indexes were calculated by:

$r_{t, i}=\ln \left(y_{t, i} / y_{t-1, i}\right)$

$r_{t, i}=i^{\text {th }}$ stock or index return at time $t$,

$y_{t, i}, y_{t-1, i}=i^{t h}$ stock price or index value for time $t$ and $t-1$ respectively. 
In order to investigate the existence of day of the week effect, regression model was constructed by the use of daily dummies. The model utilized in the study was presented in the following equation:

$r_{t, i}=\beta_{1} D M+\beta_{2} D T+\beta_{3} D W+\beta_{4} D T H+\beta_{5} D F+e_{i}$

$r_{i, t}=i^{\text {th }}$ stock or index return at time $t$

DM, DT, DW, DTH, DF = the dummy for Monday; Thursday, and etc..

By the use of regression model given above, the existence of the day of the week effect in ISE was analyzed from four different aspects. First of all, the day of the week effect in ISE-100 index, which is accepted as a market indicator, was questioned. The daily returns during 1995-2008 for the ISE-100 index was utilized for this purpose. After this analyzes, as a second aspect, the existence of the day of the week effect was examined separately for each stock that were considered in ISE-100 index. A similar analysis, as a third aspect, was carried out for 324 stocks traded in the ISE. And hence, a last analysis was done on the basis of stock market capitalization value. By the use of year end market capitalization values, stocks were divided into five groups from highest value to the lowest for each year. Each group was considered as a portfolio and daily portfolio returns were calculated by taking the equally weighted average of stock returns in the same portfolio. Hence, the existence of the day of the week effect was analyzed for each portfolio.

\section{EMPIRICAL FINDINGS}

The following tables through 2-5 summaries the empirical finding of the study (all results can be provided upon request). Table 2 provides the regression results for ISE-100 index returns. It is obvious that the negative Monday return and positive Thursday and Friday returns are significant at 5\% level. On the other hand, there is no significant return pattern for Tuesday and Wednesday.

Table 2 Day of the Week Effect for ISE-100 Index

\begin{tabular}{lcc}
\hline & Regression Coefficient & P Value \\
\hline Monday & $-0,215$ & 0,045 \\
Tuesday & 0,023 & 0,829 \\
Wednesday & 0,118 & 0,269 \\
Thursday & 0,361 & 0,001 \\
Friday & 0,383 & 0,000 \\
\hline
\end{tabular}

Table 3 summarizes the findings of the regression analysis for the stocks, which are considered in calculation of the ISE-100 index. In Table 3, the total number of significant regression coefficients is given for each day of the week among 100 stocks. The $35 \%$ of the ISE-100 index stocks displays a significant negative Monday returns, and $46 \%$ and $47 \%$ of the ISE-100 index stocks displays a significant positive Thursday and Friday returns, respectively. Although, there are some stocks which presented significant return patterns in other days, they are negligible.

Table 3 Day of the Week Effect for Stocks Considered in ISE-100 Index

\begin{tabular}{|c|c|c|c|}
\hline & Significant Positive Return* & Significant Negative Return* & Total Number of Companies \\
\hline Monday & 0 & 35 & 35 \\
\hline Tuesday & 0 & 2 & 2 \\
\hline Wednesday & 1 & 2 & 2 \\
\hline Thursday & 46 & 1 & 47 \\
\hline Friday & 47 & 0 & 47 \\
\hline
\end{tabular}

*5\% significance level

Table 4 summarizes the findings of the regression analysis for all stocks traded in ISE during 1995-2008. In Table 4, the total number of significant regression coefficients is given for each day of the week among 324 stocks. 
Total of 108 stocks displays a significant negative Monday returns. Furthermore, for 142 and 122 companies have significant positive Thursday and Friday returns, respectively. There are more significant positive returns for Thursdays than Fridays.

Table 4 Day of the Week Effect for ISE Traded Stocks

\begin{tabular}{lccc}
\hline \multicolumn{1}{c}{ Day of the Week } & \multicolumn{2}{c}{$\begin{array}{c}\text { Number of Companies } \\
\text { Significant }\end{array}$} & Tegative Return* \\
& Significant Positive Return* & 108 & 108 \\
\hline Monday & 0 & 9 & 10 \\
Tuesday & 1 & 9 & 10 \\
Wednesday & 1 & 1 & 143 \\
Thursday & 142 & 0 & 122 \\
Friday & 122 & 127 & 393 \\
\hline TOTAL & 266 & & \\
\hline
\end{tabular}

* 5\% significance level

And hence, a last analysis was done on the basis of stock market capitalization value. By the use of year end market capitalization values, stocks were divided into five groups from highest value to the lowest for each year. Each group was considered as a portfolio and daily portfolio returns were calculated by taking the equally weighted average of stock returns in the same portfolio. Hence, the existence of the day of the week effect was analyzed for each portfolio.

Table 5 Day of the Week Effect for Portfolio Returns

\begin{tabular}{|c|c|c|c|c|c|}
\hline \multirow{2}{*}{ Day of the Week } & \multicolumn{5}{|c|}{ Market Value Based Portfolio } \\
\hline & P1 & $\mathbf{P 2}$ & P3 & $\mathbf{P 4}$ & P5 \\
\hline Monday & $\overline{-}$ & - & - & - & - \\
\hline Tuesday & ns. & ns. & ns. & ns. & ns. \\
\hline Wednesday & ns. & ns. & ns. & ns. & ns. \\
\hline Thursday & + & + & + & + & + \\
\hline Friday & + & + & + & + & + \\
\hline
\end{tabular}

n.s. : Not significant, - : Significant negative return, + : Significant positive return

* 5\% significance level

Table 5 presents the findings of the regression analysis for portfolios which are constructed according to market capitalization value. The first portfolio, denoted by P1, is composed of the stock with the lowest market capitalization. On the other hand, the fifth portfolio, denoted by P5, is composed of the stock with the highest market capitalization. Regardless of the market capitalization, all portfolios presented significant negative Monday and significant positive Thursday and Friday returns. No significant results can be found out for Tuesdays and Wednesdays.

\section{CONCLUSION}

In this study, the existence of day of the week effect for ISE was analyzed on the basis of ISE-100 index returns, the returns of all stocks traded in ISE and market capitalization based portfolio returns. In line with the previous findings, the results of the study presented that the ISE-100 index, ISE traded stocks and market capitalization based portfolios had significant negative Monday and significant positive Thursday and Friday returns.

When all of the findings are considered, the ratio significant positive returns on Thursdays are higher than the significant returns for Fridays. 


\section{AUTHOR INFORMATION}

Murat Çinko has PhD. of Statistics at Marmara University Social Sciences Institute. His research area is financial econometrics.

Emin Avci has PhD. of Accounting and Finance at Marmara University, Istanbul. His research areas are derivative instruments and forecasting in financial markets.

\section{REFERENCES}

1. Ajayi, R.A., Mehdian, S., Perry, M.J. (2004). The Day-of-the-Week Effect in Stock Returns Further Evidence from Eastern European Emerging Markets, Emerging Markets Finance and Trade, vol.40, No.4, 53-62.

2. Brooks, C., Persand, G. (2001). Seasonality in Southeast Asian Stock Markets: Some New Evidence on Day-of-the Week Effects, Applied Econometric Letters, 8, 155-158.

3. Chusanachoti, J., Kamath, R. (2002, ). Market Conditions, Return Distributions, and the Day of the Week Effects in Thailand: The New Experience of 1990s, American Business Review, 6-14.

4. Cinko, M. (2008), İMKB-100 Endeksinin Gün İçi Getirisinde İstatistiksel Testler ile Anomal Testi, Beta, İstanbul.

5. Cross, F., (1973). The Behavior of Stock Prices on Friday and Monday, Financial Analysts Journal, 67-69.

6. Demirer, R., Karan, M.B. (2002). An Investigation of the Day-of-the-Week Effect on Stock Returns in Turkey, Emerging Markets Finance and Trade, 38, 6, 47-77.

7. Fact Book 2008, Istanbul Stock Exchange.

8. Fama, E. F.(1965) The Behavior of Stock Market Price, Journal of Business, January, p 34 - 105.

9. French, K.R. (1980). Stock Return and the Weekend Effect, Journal of Financial Economics, 8, 55-70.

10. Gibbons, M.R. and Hess, P. (1981). Day of the Week Effects and Asset Returns, Journal of Business, 54, 4, 579-596.

11. Gregoriou, A., Kontonikas, A., Tsitsianis, N. (2004). Does the Day of the Week Effect Exit Once Transaction Costs have been Accounted for? Evidence from the UK, Applied Financial Economics, 14, 215-220.

12. Hui, T.K. (2005). Day of the Wek Effects in US and Asia - Pasific Stock Markets During the Asian Financial Crisis: A Nonparametric Approach, Omega, 33, 277-282.

13. Keim, D.B., Stambaugh, R.F. (1984). A Further Investigation of the Weekend Effect in Stock Return, Journal of Finance, 39, 3, 819-35.

14. Kiymaz, H., Berument, H. (2003). The Day of the Week Effect on Stock Market Volatility and Volume: International Evidence, Review of Financial Economics, 12, 363-380.

15. Rogalski, R.J. (1984). New Findings Regarding Day-of-the-Week Returns over Trading and Non-Trading Periods, Journal of Finance, 43, 3, 701-717.

16. Tonchev, D. and Kim, T.H. (2004). Calendar Effects in Eastern European Financial Markets: Evidence from Czech Republic, Slovakia and Slovenia, Applied Financial Economics, 14, 1035-1043. 


\section{NOTES}

